Syntax Literate : Jurnal Ilmiah Indonesia p-ISSN: 2541-0849

e-ISSN : 2548-1398

Vol. 5, No. 10, Oktober 2020

\title{
GAMBARAN FAKTOR-FAKTOR YANG BERHUBUNGAN DENGAN KEJADIAN STUNTING BALITA USIA 24-59 BULAN
}

\section{Rina Nuraeni dan Suharno}

Sekolah Tinggi Ilmu Kesehatan (STIKes) YPIB Majalengka Jawa Barat, Indonesia

Email: rinasyifa79@gmail.com dan harnomilano@gmail.com

\section{Abstract}

This study aims to determine factors the relationship between the incidence of stunting among children aged 24-59 months in the Work Area of Kadipaten CHC, Majalengka District in 2019. This was a quantitative study with cross sectional design. The samples in this study were 328 children and parents of children aged 24-59 months in the work area of Kadipaten CHC, taken with simple random sampling technique. This study was conducted in February-July 2020. Data were analyzed using univariate analysis with frequency distribution and bivariate analysis with chi square test. The results showed that among children aged 24-59 months in the Work Area of Kadipaten CHC, in 2019, children aged 24-59 months $11.3 \%$ experienced stunting, with an education parents level of $3.75 \%, 37.8 \%$ of family heads are not working, low socioeconomic status (36.6\%), age range 24-59 months (37.8\%), male gender (50.9\%), 36.6\% LBW, birth length 40.2\%, breastfeeding pattern (36.6\%), parenting style (39.6\%), immunization status (41.2\%), and history of infection (36.6\%). and there was a significant relationship between the factor and the incidence of stunting in the Work Area of Kadipaten CHC, Majalengka District in 2019, except factor age group, sex, LBW, breastfeeding pattern and immunization status due to $p$ value> 0.05 . CHC should collaborate with cadres in conducting routine posyandu activities and providing health education about stunting and collaborating with related agencies to motivate mothers to participate in posyandu activities regularly every month, an effort to provide education about stunting which will have an impact on preventing stunting.

Keywords: Stunting; Nutrition; Children aged 24-59 months

\section{Abstrak}

Tujuan dari penelitian ini untuk mengetahui factor-faktir yang mempengaruhi kejadian stunting anak usia 24-59 tahun di Wilayah Kerja Puskesmas Kadipaten Kabupaten Majalengka Tahun 2019. Jenis penelitiannya yaitu kuantitatif dengan desain cross sectional. Sampel penelitian ini ialah balita dan orang tua balita usia 24-59 bulan di Wilayah Kerja Puskesmas Kadipaten Kabupaten Majalengka sebanyak 328 orang dengan teknik simple random sampling. Waktu penelitian yaitu bulan Februari-Juli 2020. Analisis data meliputi analisis univariat dengan distribusi frekuensi serta analisis bivariat dengan chi square-test. Hasil penelitian menunjukan balita usia 24-59 bulan di Wilayah Kerja Puskesmas Kadipaten Kabupaten Majalengka Tahun 2019 sebesar 11,3\% mengalami stunting, dengan tingkat pendidikan 3.75\%, 37.8\% kepala keluarga tidak bekerja, status sosial ekonomi 
rendah $(36.6 \%)$, rentang usia $24-59$ bulan $(37,8 \%)$, jenis kelamin laki-laki $(50,9 \%)$, $36.6 \%$ BBLR, panjang lahir 40.2\%, pola pemberian ASI (36.6\%), pola asuh anak (39.6\%), status imunisasi (41.2\%), dan riwayat infeksi (36.6\%). Dan ada hubungan yang bermakna faktor-faktor dengan kejadian stunting di Wilayah Kerja Puskesmas Kadipaten Kabupaten Majalengka Tahun 2019, kecuali factor kelompok usia, jenis kelamin, BBLR dan status imunisasi dikarenakan $\mathrm{p}$ value $>0.05$. Pihak Puskesmas bekerja sama dengan instansi terkait, kader dalam upaya penyuluhan tentang stunting, dan memotivasi ibu untuk rutin membawa anaknya ke posyandu yang akan berpengaruh terhadap pencegahan stunting.

Kata kunci: Stunting Gizi; Anak Usia 24-59 bulan

\section{Pendahuluan}

Kesehatan anak dalam pembangunan kesehatan suatu bangsa mempunyai peran yang penting, karena anak adalah generasi penerus bangsa di masa mendatang. Usaha membentuk generasi emas diikuti adanya persoalan stunting yang beresiko. Stunting mengindikasi pada keadaan lebih pendek dari tinggi badan seumurannya. Terjadinya stunting karena kekurangan gizi dalam masa yang lama pada 1.000 hari pertama kehidupan (HPK) (RI, 2016).

Masalah gizi pada anak terutama perlu ditangani dengan tepat karena berpotensi terhadap tingginya angka kematian. Menurut Laporan Global Nutrition Report tahun 2018, balita yang mengalami kejadian stunting di dunia sebanyak 150,8 juta $(22,2 \%)$ dari balita didunia (Kemenkes RI, 2019).Indonesia adalah salah satu negara dengan kejadian stunting di dunia dengan urutan ke-5 terbanyak. Dari jumlah balita di dunia sebanyak 195,1 juta negara India adalah negara dengan kejadian stunting paling tinggi yaitu 60.788 kasus $(31,2 \%)$, disusul berikutnya oleh negara China sebanyak 12.685 kasus (6,5\%), Nigeria sebanyak 10.158 kasus (5,2\%), Pakistan sebanyak 9.868 kasus $(5,1 \%)$. Kemudian Indonesia dengan jumlah kasus sebanyak 7.688 kasus $(3,9 \%)$ (Kemenkes RI, 2019).

Hasil Riskesdas tahun 2018 menyajikan prevalensi stunting di wilayah nasional sejumlah 30,8\%, yakni prevalensi pendek 19,3\% serta sangat pendek sebesar 11,5\%. Sementara tahun 2017, prevalensi stunting di Indonesia sebesar 29,0\% yang terdiri dari prevalensi pendek 19,8\% serta sangat pendek sejumlah 9,8\%. Informasi demikian mengindikasikan bahwa kejadian stunting pada balita di Indonesia tahun 2017-2018 mengalami kenaikan sebesar $1,8 \%$ dan menjadi persoalan kesehatan masyarakat yang berat karena prevalensi stunting di Indonesia berkisar antara 30-39\% (Kemenkes RI, 2019). Sedangkan di Provinsi Jawa Barat pada tahun 2018, balita yang mengalami stunting sangat pendek $11,70 \%$ serta yang pendek sejumlah $19,40 \%$ dan pada tahun 2017 balita yang mengalami stunting sangat pendek sebesar $8,40 \%$ serta yang pendek sebesar 20,80\% (Barat, 2018).

Merujuk data Dinas Kesehatan Kabupaten Majalengka tahun 2019, dari jumlah 88.139 bawah lima tahun atau balita, yang mengalami kejadian balita pendek sebanyak 3.905 balita $(4,43 \%)$ dan yang sangat pendek sebanyak 737 balita $(0,84 \%)$. Sedangkan pada tahun 2018 balita yang mengalami balita pendek (stunting) sebanyak 1.958 balita 
(2,19\%) dari jumlah 89.541 balita. Ini artinya bahwa kejadian stunting pada balita di Kabupaten Majalengka mengalami kenaikan sebesar 2,24\% yaitu dari 2,19\% menjadi 4,43\% tahun 2018 (Majalengka, 2019).

Berdasarkan laporan pada Bulan Penimbangan Balita (BPD) di wilayah kerja Puskesmas Kadipaten tahun 2018 terdapat 17 orang balita umur 24-59 bulan yang mengalami stunting dari total 3262 balita yang dilakukan pengukuran. Desa yang memiliki prevalensi stunting tertinggi yaitu Desa Liangjulang dan pada tahun 2019 terdapat balita yang mengalami stunting sebanyak 4,6\%.

Balita ialah suatu masa usia manusia setelah bayi dengan umur antara dua hingga lima tahun, juga bisa memakai perhitungan bulan yakni umur 1-5 tahun. Balita ini terdiri dari dua kelompok yaitu usia troddler dan usia preschool. Usia troddler yaitu usia 1-3 tahun, pada fase tersebut seorang anak mulai belajar memutuskan arah perkembangan dirinya, sebuah masa yang melatar belakangi bagaimana tingkat kesehatan, perkembangan emosional, tingkat pendidikan, kepercayaan diri, kapabilitas sosial serta diri seorang anak di waktu yang akan datang. Sedangkan usia preschool yaitu usia 4-6 tahun, anak dalam proses tumbuh kembang yang begitu cepat, maka membutuhkan stimulasi intensif dari orang di lingkungannya agar memiliki kepribadian yang berkualitas dalam waktu yang akan datang (Sudiaoetama, 2015).

Kejadian stunting pada balita dapat menyebabkan berbagai dampak atau kerugian. Kerugian akibat stunting bagi pemerintah yaitu naiknya pengeluaran untuk jaminan kesehatan nasional yang berkaitan dengan penyakit tidak menular yakni jantung, stroke, diabetes maupun gagal ginjal. Masa dewasa, anak yang mengidap stunting rentan mengalami kegemukan maka mudah terserang penyakit tidak menular misalnya jantung, stroke maupun diabetes (Kemenkes RI, 2019).

Kejadian stunting dapat terus meningkat apabila faktor risiko stunting di suatu daerah belum diketahui. Hal tersebut dapat berakibat pada sulitnya upaya pencegahan kejadian kekurangan gizi kronis secara dini. Gizi buruk kronis diakibatkan oleh banyak faktor, yang mana faktor itu saling berkaitan. Tiga Faktor fundamental penyebab stunting yakni tidak seimbangnya asupan makanan, riwayat berat badan lahir rendah serta riwayat penyakit (Wiyogowati, 2012).

Persoalan stunting pada balita harus memperoleh perhatian intensif selain menyebabkan kerugian bagi pemerintah, juga memberi pengaruh negatif baik jangka pendek/jangka panjang. Menurut (Kemenkes, 2017), pengaruh negatif yang diakibatkan stunting dalam jangka pendek ialah terhambatnya perkembangan otak, kecerdasan, gangguan pertumbuhan fisik, serta gangguan metabolisme dalam tubuh. Adapun dalam jangka panjang pengaruh negatif yang bisa timbul yakni melemahnya kemampuan kognitif serta prestasi belajar, menurunnya daya tahan tubuh sehingga rentan sakit, juga mempunyai resiko tinggi menimbulkan penyakit diabetes, kegemukan, penyakit jantung serta pembuluh darah, kanker, stroke, juga disabilitas di masa lansia.

Banyak faktor yang menyebabkan kejadian stunting pada balita 1-5 tahun. Menurut Kementerian Kesehatan RI, faktor-faktor penyebab stunting ialah penyebab gizi buruk yang dialami oleh ibu hamil serta anak balita, minimnya pemahaman ibu 
terkait kesehatan serta gizi sebelum serta pada fase kehamilan, tebatasnya layanan kesehatan diantaranya layanan antenatal care, masih minimnya akses kepada makanan bergizi serta kurangnya akses ke air bersih serta sanitas. Sedangkan menurut Aridiyah, faktor determinan terjadinya anak stunting ialah faktor makanan seperti asupan energi, protein juga seng. Sedangkan faktor risiko stunting dapat disebabkan oleh faktor pendapatan keluarga, jumlah anggota keluarga, pendidikan ibu, pengetahuan ibu, riwayat pemberian ASI, berat badan saat lahir serta kelengkapan imunisasi (Aridyah, Farah Okky, 2013).

Berat badan saat lahir rendah merupakan penyebab balita mengalami stunting. Bayi dengan berat badan lahir rendah (BBLR) akan mengalami hambatan pada tumbuh kembang juga kemungkinan akan mengalami kemunduran fungsi intelektualnya, disamping itu bayi lebih mudah terjangkit infeksi serta terjadi hipotermi. Keterlambatan tumbuh kembang dapat dilihat dari fisik BBLR yaitu berat badan rendah $<2500$ gram. Stunting yang sudah terjadi jika tidak diimbangi dengan catch-up growth (kejar tumbuh) akan menyebabkan penurunan pertumbuhan ((IDAI), 2015).

Pengetahuan perihal gizi sangat dibutuhkan supaya bisa menanggulangi persoalan-persoalan yang muncul karena asupan gizi. Perempuan khususnya ibu yang berkewajiban pada asupan makanan untuk keluarga. Ibu perlu mempunyai pemahaman perihal gizi bisa didapatkan dari pendidikan formal/non-formal (Sudiaoetama, 2015). Sedangkan menurut (Notoatmodjo, 2015), tingkat pendidikan berpengaruh terhadap seseorang dalam menerima informasi terkait gizi terutama ibu. Ibu akan lebih mudah menerima informasi gizi dengan jenjang pendidikan yang lebih baik dibandingkan dengan jenjang pendidikan yang kurang. Fakta itu menjadi bekal ibu untuk mengurus balitanya dalam kesehariannya sehingga dapat mencegah kejadian stunting.

Status social ekonomi keluarga dihambarkan oleh penghasilan keluarga atau pendapatan keluarga yang juga penentu utama yang berkaitan dengan kualitas makanan. Jika penghasilan keluarga meningkat, penyediaan lauk pauk akan bertambah pula mutunya. Tidak bisa dipungkiri bahwa pendapatan keluarga ikut berpengaruh pada makanan yang disajikan bagi keluarga sehari-hari, dari kualitas ataupun kuantitas makanan (Susianto, 2014). Peningkatan pendapatan akan memiliki pengaruh terhadap perbaikan kesehatan serta keadaan keluarga serta selanjutnya berkaitan dengan status gizi. Tetapi peningkatan pendapatan ataupun daya beli seringkali tidak bisa mengalahkan dampak kebiasaan makan pada perbaikan gizi yang efektif (Beck, 2011). Penelitian ini sangat penting dilakukan karena dapat menambah informasi dalam bidang kesehatan yaitu dapat menjadi gambaran tentang kejadian stunting dan menjadi bahan masukan dalam penanganan stunting dengan metode yang tepat untuk meningkatkan kualitas peningkatan tumbuh kembang balita.

\section{Metode Penelitian}

Penelitian ini menggunakan metode kuantitatif dengan desain cross sectional. Tujuannya untuk memahami keterkaitan status sosial ekonomi keluarga dengan keadaan 
stunting pada balita usia 24-59 bulan di Wilayah Kerja Puskesmas Kadipaten Kabupaten Majalengka Tahun 2019.

Populasinya ialah orang tua dan balita usia 24-59 bulan di Wilayah Kerja Puskesmas Kadipaten Kabupaten Majalengka. Adapun sampelnya ialah balita dan orang tua balita usia 24-59 bulan sejumlah 328 orang dengan teknik simple random sampling. Data penelitian ini berupa data primer hasil pengukuran antropometri balita dan juga menggunakan instrument penelitian berupa kuesioner yang berisi pertanyaan yang akan diajukan kepada responden.

Analisa data pada penelitian ini terdiri dari Analisa Univariat untuk analisis masing-masing variable penelitian dengan distribusi frekuensi dan Analisa Bivariat terhadap dua variable yang diduga berkaitan satu dengan yang lainnya memakai uji chi square. Setelah mendapat izin penelitian, selanjutnya yaitu melaksanakan penelitian dengan ditekankan pada persoalan etika terdiri dari Lembar Persetujuan (Inform Consent), Tanpa Nama (Anonymity), Kerahasiaan (Confidentiality) dan manfaat (Benefience).

\section{Hasil dan Pembahasan}

A. Gambaran Kejadian Stunting pada Balita Usia 24-59 bulan di Wilayah Kerja Puskesmas Kadipaten Kabupaten Majalengka Tahun 2019

\section{Tabel 1}

Distribusi Frekuensi Kejadian Stunting pada Balita Usia 24-59 bulan di Wilayah Kerja Puskesmas Kadipaten Kabupaten Majalengka Tahun 2019

\begin{tabular}{ccc}
\hline Status Gizi & F & $(\%)$ \\
\hline Stunting & 37 & 11.3 \\
Normal & 291 & 88.7 \\
\hline Total & 328 & 100 \\
\hline
\end{tabular}

Berdasarkan tabel 1 diatas dapat diketahui balita usia 24- 59 bulan di Wilayah Kerja Puskesmas Kadipaten Kabupaten Majalengka Tahun 2019 yang mempunyai status gizi pendek (stunting) sebanyak 37 balita (11,3\%) dan sisanya sebanyak 291 balita $(88,7 \%)$ memiliki status gizi normal. Hal ini menunjukan sebagian kecil $(11,3 \%)$ balita usia 24-59 bulan di Wilayah Kerja Puskesmas Kadipaten Kabupaten Majalengka Tahun 2019 mengalami stunting. 
B. Gambaran Faktor-faktor Yang Berpengaruh terhadap Kejadian Stunting pada Balita Usia 24-59 bulan di Wilayah Kerja Puskesmas Kadipaten Kabupaten Majalengka Tahun 2019

Tabel 2

Distribusi Frekuensi Kejadian Stunting pada Balita Usia 24-59 bulan di Wilayah Kerja Puskesmas Kadipaten Kabupaten Majalengka Tahun 2019

\begin{tabular}{|c|c|c|}
\hline Faktor Yang Mempengaruhi Stunting & $\mathrm{F}$ & $\%$ \\
\hline $\begin{array}{l}\text { 1. Tingkat Pendidikan Orang Tu } \\
\text { Balita 24-59 bulan }\end{array}$ & & \\
\hline Rendah & 123 & 37.5 \\
\hline Tinggi & 205 & 62.5 \\
\hline \multicolumn{3}{|l|}{ 2. Pekerjaan Kepala Keluarga } \\
\hline Tidak Bekerja & 124 & 37.8 \\
\hline Bekerja & 204 & 62.2 \\
\hline \multicolumn{3}{|l|}{ 3. Status Ekonomi Keluarga } \\
\hline Rendah & 120 & 36.6 \\
\hline Tinggi & 208 & 63.4 \\
\hline \multicolumn{3}{|l|}{ 4. Kelompok Usia } \\
\hline $24-36$ bulan & 124 & 37.8 \\
\hline $37-59$ bulan & 201 & 61.3 \\
\hline \multicolumn{3}{|l|}{ 5. Jenis Kelamin } \\
\hline Laki-laki & 167 & 50.9 \\
\hline Perempuan & 161 & 49.1 \\
\hline \multicolumn{3}{|l|}{ 6. BBLR } \\
\hline$<2500$ gram & 137 & 41.8 \\
\hline$\geq 2500$ gram & 191 & 58.2 \\
\hline \multicolumn{3}{|l|}{ 7. Panjang Badan Lahir } \\
\hline$<46 \mathrm{~cm}$ & 132 & 40.2 \\
\hline$\geq 46 \mathrm{~cm}$ & 196 & 58.8 \\
\hline \multicolumn{3}{|l|}{ 8. Pola Pemberian ASI } \\
\hline Petugas Kesehatan & 21 & 21.9 \\
\hline Sendiri & 19 & 19.8 \\
\hline 9. Pola Asuh Anak & $\mathrm{F}$ & $\%$ \\
\hline Kurang Baik & 130 & 39.6 \\
\hline Baik & 198 & 60.4 \\
\hline 10. Status Imunisasi & $\mathrm{F}$ & $\%$ \\
\hline Tidak Lengkap & 135 & 41.2 \\
\hline Lengkap & 193 & 58.8 \\
\hline 11. Riwayat Infeksi & $\mathrm{f}$ & $\%$ \\
\hline Ya, ada riwayat & 135 & 41.2 \\
\hline Tidak ada & 193 & 58.8 \\
\hline Total & 328 & 100 \\
\hline
\end{tabular}


Berdasarkan tabel 3 diatas menunjukan kurang dari setengah orang tua balita usia 24-59 bulan di Wilayah Kerja Puskesmas Kadipaten Kabupaten Majalengka Tahun 2019 berpendidikan rendah (37,7\%). Kurang dari setengah orang tua balita usia 24-59 bulan di Wilayah Kerja Puskesmas Kadipaten Kabupaten Majalengka Tahun 2019 tidak bekerja (37,8\%). Kurang dari setengahnya $(36,6 \%)$ status ekonomi keluarga pada kelompok balita usia 24-59 bulan di Wilayah Kerja Puskesmas Kadipaten Kabupaten Majalengka Tahun 2019 dengan status ekomomi rendah. Kurang dari setengah balita usia di Wilayah Kerja Puskesmas Kadipaten Kabupaten Majalengka Tahun 2019 berada pada rentang usia24-59 bulan (37,8\%). Berdasarkan jenis kelamin balita 24-59 bulan menunjukan lebih dari setengah balita di Wilayah Kerja Puskesmas Kadipaten Kabupaten Majalengka Tahun 2019 berjenis kelamin laki-laki (50,9\%). Menunjukan kurang dari setengah balita di Wilayah Kerja Puskesmas Kadipaten Kabupaten Majalengka Tahun 2019 memiliki riwayat BBLR $<2500$ gram sebanyak 137 balita (41,8\%). Kurang dari setengah balita di Wilayah Kerja Puskesmas Kadipaten Kabupaten Majalengka Tahun 2019 mempunyai riwayat dengan panjang badan saat lahir $<46 \mathrm{~cm}$ sebanyak 132 balita (40,2\%). Kurang dari setengah balita di Wilayah Kerja Puskesmas Kadipaten Kabupaten Majalengka Tahun 2019 memiliki riwayat pemberian ASI non Eksklusif sebanyak 120 balita $(36,6 \%)$. Kurang dari setengah balita di Wilayah Kerja Puskesmas Kadipaten Kabupaten Majalengka Tahun 2019 memiliki riwayat pola asuh kurang baik sebanyak 130 balita $(39,8 \%)$. Kurang dari setengah balita di Wilayah Kerja Puskesmas Kadipaten Kabupaten Majalengka Tahun 2019 mempunyai riwayat status imunisasi tidak lengkap sebanyak 135 balita (41,2\%). Kurang dari setengah balita di Wilayah Kerja Puskesmas Kadipaten Kabupaten Majalengka Tahun 2019 ada riwayat penyakit infeksi sebanyak 120 balita $(36,6 \%)$. 
C. Keterkaitan Faktor-faktor Terhadap Kejadian Stunting Pada Balita 24-59 bulan di UPTD Puskesmas Kadipaten Kabupaten Majalengka Tahun 2020.

Tabel 3

Distribusi Proporsi Faktor-faktor Yang Berkaitan Dengan Kejadian Stunting Balita Usia 24-59 Bulan di Wilayah Kerja Puskesmas Kadipaten Kabupaten Majalengka Tahun 2020

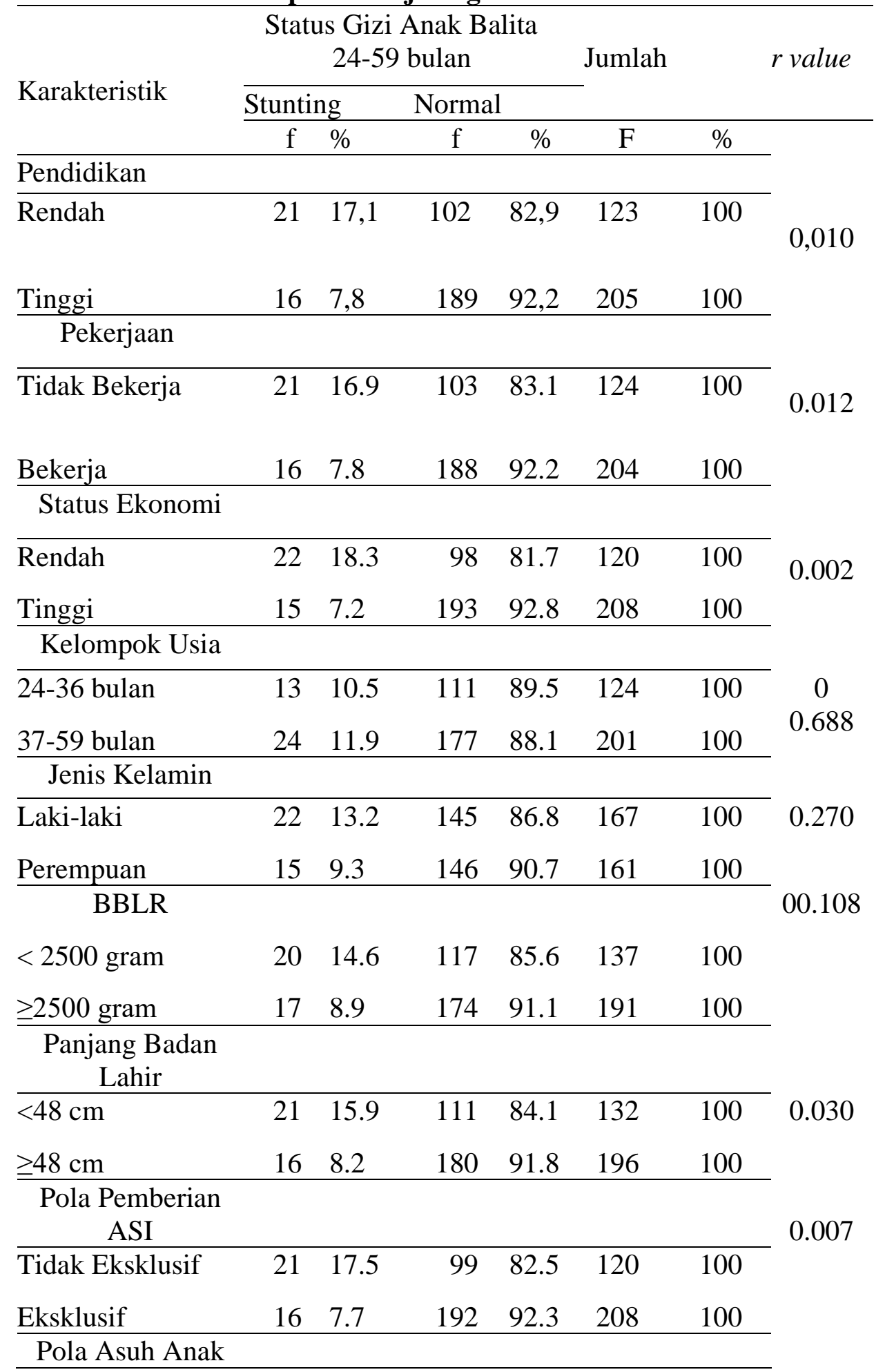




\begin{tabular}{|c|c|c|c|c|c|c|c|}
\hline Kurang Baik & 21 & 16.2 & 109 & 83.8 & 130 & 100 & \multirow[b]{2}{*}{0.024} \\
\hline Baik & 16 & 8.1 & 182 & 91.9 & 198 & 100 & \\
\hline \multicolumn{7}{|c|}{ Status Imunisasi } & \multirow{3}{*}{0.181} \\
\hline Tidak Lengkap & 19 & 14.1 & 116 & 85.9 & 135 & 100 & \\
\hline Lengkap & 18 & 9.3 & 175 & 90.7 & 193 & 100 & \\
\hline \multicolumn{7}{|c|}{$\begin{array}{c}\text { Riwayat Penyakit } \\
\text { Infeksi } \\
\end{array}$} & \multirow{4}{*}{0.019} \\
\hline Ya, ada riwayat & 20 & 16.7 & 100 & 83.3 & 120 & 100 & \\
\hline Tidak ada & 17 & 8.2 & 191 & 91.8 & 208 & 100 & \\
\hline Total & 37 & 11.3 & 291 & 88.7 & 328 & 100 & \\
\hline
\end{tabular}

Berdasarkan tabel 4 Hasil perhitungan statistic menggunakan chy square, Menunjukkan bahwa balita usia 24-59 bulan di Wilayah Kerja Puskesmas Kadipaten Kabupaten Majalengka Tahun 2019 diketahui $p \cdot$ Value $=0,01\left(p_{\text {Value }}<0,05\right)$, Terdapat kaitan yang bermakna diantara status pendidikan orang tua balita serta kejadian stunting di Wilayah Kerja Puskesmas Kadipaten Kabupaten Majalengka Tahun 2019. Hasil penelitian ini lebih rendah dibanding dengan hasil penelitian (Nadiyah, Briawan, \& Martianto, 2014) di Provinsi Bali, Jawa Barat, dan Nusa Tenggara Timur mengindikasikan pendidikan orang tua yang rendah sebesar 70,5\%. Jenjang pendidikan berdampak pada seseorang dalam menerima pengetahuan terkait gizi terutama ibu. Ibu dengan jenjang pendidikan yang lebih baik maka lebih mudah dalam mendapatkan pengetahuan gizi dibandingkan orang dengan jenjang pendidikan yang kurang. Pengetahuan itu menjadii bekal ibu untuk mengasuh balitanya dalam kehidupan sehari-hari maka bisa mencegah kejadian stunting (Notoatmodjo, 2015).

Status pekerjaan orang tua dari hasil uji statistik Chi Square diketahui $p$. value $=$ $0,012\left(p_{\text {Value }}<0,05\right)$ Terdapat kaitan yang bermakna diantara status pekerjaan orang tua balita dengan kejadian stunting diWilayah Kerja Puskesmas Kadipaten Kabupaten Majalengka Tahun2019. Hasil serupa didapatkan pada penelitian (Anisa, 2012) yang menyatakan bahwa proporsi ibu balita yang tidak bekerja mempunyai anak denga status gizi stunting lebih banyak yakni $23 \%$ daripada dengan ibu yang bekerja yakni sebesar 11,8\%.

Status sosial ekonomi hasil uji statistik Chi Square diketahui $p \cdot$ value $=0,02(p$ Value $<0,05)$ Ada kaitan yang bermakna diantara status sosial ekonomi keluarga balita dengan kejadian stunting di Puskesmas Wilayah Kerja Puskesmas Kadipaten Kabupaten Majalengka Tahun2019. Menurut (Beck, 2011) kenaikan pendapatan akan berdampak pada penyempurnaan kesehatan serta keadaan keluarga. Setelah itu berkaitan pada kejadian stunting. Tetapi kenaikan pendapatan/daya beli kerapkali tidak bisa mengalahkan dampak kebiasaan makan pada perbaikan gizi yang efektif..

Berdasarkan kelompok usia didapatkan hasil uji statistik Chi Square diketahui $p \cdot$ value $=0,68(p$ value $>0,05)$ Tidak ada kaitan yang bermakna diantara usia 
balita dengan kejadian stunting di Wilayah Kerja Puskesmas Kadipaten Kabupaten Majalengka Tahun2019. Hasil penelitian ini tidak searah dengan (Andi Setiawan, 2018) mengindikasikan bahwa terdapat kaitan diantara umur dengan kejadian stunting pada anak usia 24-59 bulan di Wilayah Kerja Puskesmas Andalas Kecamatan Padang Timur Kota Padang juga penelitian (Lestari, Margawati, \& Rahfiludin, 2014) bahwa umur berhubungan dengan stunting pada anak usia 6-24 bulan di Kecamatan Penanggalan Kota Subulussalam Provinsi Aceh.

Berdasarkan jenis kelamin, hasil uji statistik Chi Square diketahui $p \cdot$ value $=$ 0,270 ( $\left.p_{\text {Value }}>0,05\right)$ Tidak ada hubungan yang bermakna antara jenis kelamin dengan kejadian stunting di Wilayah Kerja Puskesmas Kadipaten Kabupaten Majalengka Tahun2019. Hal ini sejalan dengan penelitian (Setyawati, 2018) dengan judul kajian stunting berdasarkan usia serta gender di kota Semarang, bahwa tidak adanya hubungan diantara jenis kelamin serta kejadian stunting dengan $p$. value $=0,46$, dan prevalensi anak yang menderita stunting lebih banyak pada anak dengan jenis kelamin laki-laki daripada perempuan, beberapan sebab diantaranya ialah pertumbuhan motorik kasar anak laki-laki lebih pesat serta beragam maka memerlukan energy tidak sedikit.

Hasil uji statistik Chi Square diketahui $p$. value $=0,108\left(p_{\text {Value }}>0,05\right)$ Tidak ada relasi yang bermakna diantara berat badan lahir dengan kejadian stunting di Wilayah Kerja Puskesmas Kadipaten Kabupaten Majalengka Tahun2019. Hasil penelitian ini tidak searah dengan penelitian (Ni'mah \& Nadhiroh, 2015) yang menyatakan bahwa separuhnya balita stunting serta normal memiliki berat badan (BB) lahir normal. Meskipun begitu, beberapa penelitian menunjukan bahwa BB lahir merupakan indikator paling baik agar tahu kondisi gizi serta tumbuh kembang anak. Sehingga berat badan lahir balita yang rendah harus tetap menjadi perhatian karena berkontribusi dalam kejadian stunting pada balita.

Hasil uji statistik Chi Square diketahui $p \cdot$ value $=0,03\left(p_{\text {value }}<0,05\right)$ Terdapat kaitan yang bermakna diantara panjang badan lahir dengan kejadian stunting di Wilayah Kerja Puskesmas Kadipaten Kabupaten Majalengka Tahun2019. Hasil penelitian tersebut searah dengan penelitian (Ni'mah \& Nadhiroh, 2015) yang menyatakan bahwa balita stunting memiliki presentasi panjang badan lahir normal sebesar $64,7 \%$. Panjang badan lahir pendek pada anak mengindikasikan kekurangan asupan zat gizi selama masa kehamilan, maka perkembangan janin tidak maksimal yang menyebabkan bayi yang lahir mempunyai panjang badan lahir pendek. Sama hal nya seperti pada penjelasan gambaran berat lahir balita, status gizi ibu hamil juga perlu diperhatikan untuk mengatasi pnajang badan lahir pendek pada balita.

Hasil uji statistik Chi Square diketahui $p$.value $=0,07$ ( $\left.p_{\text {value }}>0,05\right)$ Tidak ada hubungan yang bermakna antara pemberian ASI dengan kejadian stunting di Wilayah Kerja Puskesmas Kadipaten Kabupaten Majalengka Tahun2019.Penelitian ini tidak sejalan dengan hasil penelitian (Indrawati, 2017) di Desa Karangrejek Kecamatan Wonosari Kabupaten Gunung Kidul bahwa ada hubungan pemberian ASI eksklusif dengan kejadian stunting pada balita 2-3 tahun $(\rho=0,002)$. 
Berdasarkan teori bahwa ASI mempengaruhi keadaan gizi pada balita dikarenakan ASI mengandung zat antibodi sehingga balita yang tidak diberikan ASI eksklusif akan rentan terhadap penyakit dan akan berperan langsung terhadap status gizi balita.

Hasil uji statistik Chi Square diketahui $p \cdot$ value $=0,024(p$ value $<0,05)$, Ada hubungan yang bermakna antara pola asuh dengan kejadian stunting di Wilayah Kerja Puskesmas Kadipaten Kabupaten Majalengka Tahun 2019. Pola asuh terdiri dari pola asuh makan serta perawatan anak. Pola asuh makan ialah cara makan seseorang maupun sekelompok orang dalam menentukan makanan serta memakannya sebagai reaksi pada dampak fisiologi, psikologi budaya serta sosial. Praktek perawatan kesehatan anak di kondisi sakit ialah satu diantara aspek pola asuh yang bisa berpengaruh kepada status gizi anak.

Hasil uji statistik Chi Square diketahui $p$. value $=0,18$ ( $p$ Value $<0,05)$ tidak ada hubungan yang bermakna antara status imunisasi dengan kejadian stunting di Wilayah Kerja Puskesmas Kadipaten Kabupaten Majalengka Tahun2019. Penelitian ini tidak sejalan dengan penelitian (Lestari et al., 2014) menunjukkan bahwa ada hubungan antara riwayat imunisasi dengan dengan kejadian stunting pada anak umur 6-24 bulan di Kecamatan Penanggalan Kota Subulussalam Provinsi Aceh. Juga hasil penelitian (Eko Setiawan, Machmud, \& Masrul, 2018) menunjukkan bahwa ada hubungan antara riwayat imunisasi dengan kejadian stunting pada anak usia 24-59 bulan di Wilayah Kerja Puskesmas Andalas Kecamatan Padang Timur Kota Padang. Berdasarkan teori bahwa pemberian imunisasi adalah sebagai salah satu usaha dalam memproteksi balita agar terhindar dari penyakit. Apabila balita terhindar dari penyakit maka asupan gizi yang diberikan dapat terserap dengan optimal dan mendukung tumbuh kembang balita.

Hasil uji statistik Chi Square diketahui $p \cdot$ value $=0,01(p$ value $<0,05)$ maka terdapat kaitan yang bermakna diantara riwayat penyakit infeksi dengan kejadian stunting di Wilayah Kerja Puskesmas Kadipaten Kabupaten Majalengka Tahun2019. Penyakit infeksi ialah satu dari beberapa faktor penyebab langsung status gizi balita. Hasil penelitian ini sejalan dengan penelitian Anisa (2012) yang menunjukan bahwa keseimbangan balita yang mempunyai status gizi stunting lebih sering menderita penyakit infeksi dalam satu bulan terakhir yakni sejumlah $22,1 \%$ daripada dengan yang tidak menderita penyakit infeksi (19,4\%). Penelitian ini sama dengan penelitian (Aridiyah, Rohmawati, \& Ririanty, 2015), yang mengindikasikan bahwa ada kaitannya diantara penyakit infeksi dan kejadian stunting besat $p$. value $=$ 0,001 , pada balita di desa maupun diperkotaan mayoritas mempunyai riwayat penyakit infeksi dengan presentasi $100 \%$. 


\section{Kesimpulan}

Berdasarkan hasil penelitian sertta pembahasan terkait "Gambaran Faktor-Faktor Yang Berpengaruh terhadap Kejadian Stunting Balita Usia 24-59 Bulan Di Wilayah Kerja Puskesmas Kadipaten Kabupaten Majalengka Tahun 2019”, bisa disimpulkan beberapa hal yakni: (1) Minoritas (11,3\%) balita usia 24-59 bulan di Wilayah Kerja Puskesmas Kadipaten Kabupaten Majalengka Tahun 2019 mengalami stunting. (2) Kurang dari setengah orang tua balita usia 24-59 bulan di Wilayah Kerja Puskesmas Kadipaten Kabupaten Majalengka Tahun 2019 tidak bekerja (37,8\%). (3) Kurang dari setengahnya (36,6\%) status ekonomi keluarga pada kelompok balita usia 24-59 bulan di Wilayah Kerja Puskesmas Kadipaten Kabupaten Majalengka Tahun 2019 dengan status ekomomi rendah. (4) Kurang dari setengah balita usia usia 24-59 bulan di Wilayah Kerja Puskesmas Kadipaten Kabupaten Majalengka Tahun 2019 berada pada rentang usia $24-59$ bulan (37,8\%). (5) Lebih dari setengah balita usia 24-59 bulan di Wilayah Kerja Puskesmas Kadipaten Kabupaten Majalengka Tahun 2019 bergender laki-laki (50,9\%). (6) Kurang dari setengah balita usia 24-59 bulan di Wilayah Kerja Puskesmas Kadipaten Kabupaten Majalengka Tahun 2019 mempunyai riwayat BBLR < 2500gram sebanyak 137 balita (41,8\%). (7) Kurang dari setengah balita usia 24-59 bulan di Wilayah Kerja Puskesmas Kadipaten Kabupaten Majalengka Tahun 2019 memiliki riwayat dengan panjang badan saat lahir < $46 \mathrm{~cm}$ sebanyak 132 balita (40,2\%). (8) Kurang dari setengah balita usia 24-59 bulan di Wilayah Kerja Puskesmas Kadipaten Kabupaten Majalengka Tahun 2019 memiliki riwayat dengan panjang badan saat lahir < $46 \mathrm{~cm}$ sebanyak 132 balita (40,2\%). (9) Kurang dari setengah balita usia 24-59 bulan di Wilayah Kerja Puskesmas Kadipaten Kabupaten Majalengka Tahun 2019 memiliki riwayat pemberian ASI non Eksklusif sebanyak 120 balita (36,6\%). (10) Kurang dari setengah balita usia 24-59 bulan di Wilayah Kerja Puskesmas Kadipaten Kabupaten Majalengka Tahun 2019 memiliki riwayat pola asuh kurang baik sejumlah 130 balita (39,8\%). (11) Kurang dari setengah balita usia 24-59 bulan di Wilayah Kerja Puskesmas Kadipaten Kabupaten Majalengka Tahun 2019 mempunyai riwayat status imunisasi tidak lengkap sebanyak 135 balita $(41,2 \%)$. (12) Terdapat hubungan diantara jenjang pendidikan orang tua balita usia 24-59 bulan dan kejadian stunting di Wilayah Kerja Puskesmas Kadipaten Kabupaten Majalengka Tahun 2019. (13) Terdapat hubungan diantara status pekerjaan orang tua balita usia 24-59 bulan dengan kejadian stunting di Wilayah Kerja Puskesmas Kadipaten Kabupaten Majalengka Tahun 2019. (14) Terdapat hubungan antara Sosial Ekonomi orang tua balita usia 24-59 bulan dengan kejadian stunting di Wilayah Kerja Puskesmas Kadipaten Kabupaten Majalengka Tahun 2019. (15) Tidak terdapat hubungan antara Kelompok Usia Balita usia 24-59 bulan dengan kejadian stunting di Wilayah Kerja Puskesmas Kadipaten Kabupaten Majalengka Tahun 2019. (16) Tidak terdapat hubungan antara Jenis Kelamin Balita usia 24-59 bulan dengan kejadian stunting di Wilayah Kerja Puskesmas Kadipaten Kabupaten Majalengka Tahun 2019. (17) Tidak terdapat hubungan antara BBLR Balita usia 24-59 bulan dengan kejadian stunting di Wilayah Kerja Puskesmas Kadipaten Kabupaten Majalengka Tahun 2019. (18) Terdapat hubungan antara Panjang Badan Balita usia 24- 
59 bulan dengan kejadian stunting di Wilayah Kerja Puskesmas Kadipaten Kabupaten Majalengka Tahun 2019. (19) Tidak terdapat hubungan antara Pola Pemberian ASI Balita usia 24-59 bulan dengan kejadian stunting di Wilayah Kerja Puskesmas Kadipaten Kabupaten Majalengka Tahun 2019. (20) Terdapat hubungan antara Pola Asuh Anak Balita usia 24-59 bulan dengan kejadian stunting di Wilayah Kerja Puskesmas Kadipaten Kabupaten Majalengka Tahun 2019. (21) Tidak terdapat hubungan antara Status Imunisasi Balita usia 24-59 bulan dengan kejadian stunting di Wilayah Kerja Puskesmas Kadipaten Kabupaten Majalengka Tahun 2019. (22) Terdapat hubungan antara Riwayat Penyakit Infeksi Balita usia 24-59 bulan dengan kejadian stunting di Wilayah Kerja Puskesmas Kadipaten Kabupaten Majalengka Tahun 2019. 


\section{BIBLIOGRAFI}

(IDAI), Ikatan Dokter Anak Indonesia. (2015). Pencegahan dan Penananganan Balita Stunting. https://www.idai.or.id/artikel/seputar-kesehatan-anak/mencegah-anakberperawakan-pendek

Anisa, Paramitha. (2012). Faktor-Faktor yang Berhubungan dengan Kejadian Stunting pada balita usia 25-60 bulan di Kelurahan Kalibaru Depok tahun 2012. Universitas Indonesia.

Aridiyah, Farah Okky, Rohmawati, Ninna, \& Ririanty, Mury. (2015). Faktor-faktor yang Mempengaruhi Kejadian Stunting pada Anak Balita di Wilayah Pedesaan dan Perkotaan (The Factors Affecting Stunting on Toddlers in Rural and Urban Areas). Pustaka Kesehatan, 3(1), 163-170.

Aridyah, Farah Okky, Ninna Rohmawati dan Mury Ririanty. (2013). Faktor-Faktor yang Mempengaruhi Kejadian Stunting padaAnak Balita di Wilayah Pedesaan dan Perkotaan. Jurnal UNEJ.

Barat, Dinkes Jawa. (2018). Profil Kesehatan Provinsi Jawa Barat Tahun 2017. Dinas Kesehatan Jawa Barat.

Beck, Mary E. (2011). Ilmu Gizi dan Diet Hubungannya dengan Penyakit-penyakit untuk perawat dan dokter. CV.Andi Offset Yogyakarta.

Indrawati, Sri. (2017). Hubungan Pemberian Asi Esklusif Dengan Kejadian Stunting Pada Anak Usia 2-3 Tahun di Desa Karangrejek Wonosari GunungkiduL. Universitas' Aisyiyah Yogyakarta.

Kemenkes, R. I. (2017). Profil kesehatan Republik Indonesia tahun 2017. Kementerian Kesehatan RI. Jakarta.

Kemenkes RI. (2019). Profil Kesehatan Indonesia 2018.https://www.kemkes.go.id/fold er/view/01/structure-publikasi-pusdatin-profil-kesehatan.html

Lestari, Wanda, Margawati, Ani, \& Rahfiludin, Zen. (2014). Faktor risiko stunting pada anak umur 6-24 bulan di kecamatan Penanggalan Kota Subulussalam Provinsi Aceh. Jurnal Gizi Indonesia (The Indonesian Journal of Nutrition), 3(1), 37-45.

Majalengka, Dinas Kesehatan Kabupaten. (2019). Profil Kesehatan Kabupaten Majalengka Tahun 2018. Majalengka: Dinas Kesehatan Kabupaten Majalengka.

Nadiyah, Nadiyah, Briawan, Dodik, \& Martianto, Drajat. (2014). Faktor Risiko Stunting Pada Anak Usia 0-23 Bulan Di Provinsi Bali, Jawa Barat, Dan Nusa Tenggara Timur. Jurnal Gizi Dan Pangan, 9(2).

Ni'mah, Khoirun, \& Nadhiroh, Siti Rahayu. (2015). Faktor yang berhubungan dengan kejadian stunting pada balita. Media Gizi Indonesia, 10(1), 13-19. 
Rina Nuraeni dan Suharno

Notoatmodjo, Soekidjo. (2015). Metodologi penelitian kesehatan. Jakarta: rineka cipta.

RI, Kementrian Kesehatan. (2016). Data Dasar Puskesmas, Kondisi Desember 2015. Jakarta.

Setiawan, Andi. (2018). Pengaruh Disiplin Kerja Terhadap Promosi Jabatan Melalui Penilaian Prestasi Kerja Sebagai Variabel Intervening (Studi pada PT Yuasa Battery Indonesia Tangerang). Universitas Mercu Buana Jakarta.

Setiawan, Eko, Machmud, Rizanda, \& Masrul, Masrul. (2018). Faktor-Faktor yang Berhubungan dengan Kejadian Stunting pada Anak Usia 24-59 Bulan di Wilayah Kerja Puskesmas Andalas Kecamatan Padang Timur Kota Padang Tahun 2018. Jurnal Kesehatan Andalas, 7(2), 275-284.

Setyawati, Vilda Ana Veria. (2018). Kajian Stunting Berdasarkan Umur dan Jenis Kelamin di Kota Semarang. Proceeding of The URECOL, 834-838.

Sudiaoetama. (2015). Ilmu Gizi untuk Mahasiswa dan Profesi. Jakarta: Dian Rakyat.

Susianto. (2014). The Miracle of Vegan. Jakarta: Qanita.

Wiyogowati, C. (2012). Kejadian stunting pada anak berumur dibawah lima tahun (0 59 tahun) di provinsi papua barat tahun 2010. 